\title{
Kitlesel Fonlama Projelerinin Başarılarını Etkileyen Faktörler Üzerine Bir İnceleme ${ }^{1}$
}

Birten AKYILDIZ (https://orcid.org/0000-0002-3985-5626), Hacettepe University, Turkey; birten.akyildiz@hacettepe.edu.tr

Selin METIN-CAMGÖZ (https://orcid.org/0000-0002-3304-7177), Hacettepe University, Turkey; selinm@hacettepe.edu.tr

Kazım Barış ATICI (https://orcid.org/0000-0003-0786-9641), Hacettepe University, Turkey; kba@hacettepe.edu.tr

\section{An Investigation on Factors Affecting Crowdfunding Project Success ${ }^{2}$}

\begin{abstract}
Crowdfunding is an alternative financing method used by entrepreneurs or businesses to fund new ventures. This study aims to investigate the factors affecting the success of crowdfunding projects. Accordingly, data on successful and unsuccessful projects in the technology and film industries were collected from crowdfunding platforms in Turkey and the United States. The factors affecting the project's success are analysed and discussed using the variables determined by a comprehensive literature review and examined within the framework of Signalling Theory and Social Network Theory. It is thought that the findings of this study, which is quite comprehensive in terms of crowdfunding projects, will be a guide for entrepreneurs who want to carry out project ownership or for studies that will investigate the effectiveness of projects.
\end{abstract}

Keywords $\quad$ : Crowdfunding, Reward-Based Funding, Signalling Theory, Crowdfunding Success Factors.

JEL Classification Codes: $\quad$ L26, M10, M13.

\section{$\ddot{\mathbf{O} z}$}

Kitlesel fonlama, yeni girişimlere fon sağlamak üzere girişimciler veya işletmeler tarafından kullanılan alternatif bir finansman yöntemidir. Bu çalışmanın amacı, kitlesel fonlama projelerinin başarısına etki eden faktörlerin araştırılmasıdır. Bu doğrultuda, Türkiye ve Amerika Birleşik Devletleri'ndeki kitlesel fonlama platformlarından teknoloji ve film sektörlerine ait başarılı ve başarısız olmuş projelerin verisi toplanmıştır. Kapsamlı bir literatür taraması ile belirlenen ve Sinyal Teorisi ile Sosyal A ̆ Teorisi çerçevesinde incelenen değişkenler kullanılarak proje başarısına etki eden faktörler analiz edilmiş ve tartışılmıştır. Kitlesel fonlama projeleri açısından oldukça kapsamlı bu çalışmanın bulgularının proje sahipliği yürütmek isteyen girişimciler veya projelerin etkinliğini araştıracak çalışmalar için yol gösterici nitelikte olacağı düşünülmektedir.

1 Bu makale, Hacettepe Üniversitesi, Sosyal Bilimler Enstitüsü, Muhasebe ve Finansman Yüksek Lisans programında sunulan "Gelişmiş ve Gelişmekte Olan Ülkelerdeki Kitlesel Fonlamanın Karşılaştırılması Üzerine Bir Inceleme" başllkl yüksek lisans tezine dayanılarak hazırlanmıştır.

2 This paper is produced based on the Master Thesis entitled as "A Review and Comparison of Crowdfunding in Developed and Developing Countries" submitted in Accounting and Finance Masters Programme at Hacettepe University, Institute of Social Sciences. 
Akyıldız, B. \& S. Metin-Camgöz \& K.B. Atıcı (2021), "Kitlesel Fonlama Projelerinin

Başarılarını Etkileyen Faktörler Üzerine Bir İnceleme”, Sosyoekonomi, 29(50), 521-545.

Anahtar Sözcükler
: $\quad$ Kitlesel Fonlama, Ödül Temelli Fonlama, Sinyal Teorisi, Kitlesel

Fonlama Başarı Faktörleri.

\section{Giriş}

Kitlesel fonlama (Crowdfunding), kitlelerin coğrafya fark etmeksizin internet aracılığg ile iletişim kurduğu kuruluş veya bireyler tarafından başlatılan etkinlikleri desteklemek için fonları bir araya getirmesine dayanan bir kitle davranışı olarak tanımlanabilir (Agrawal vd., 2011; Sancak, 2016). Bu sayede, girişimci, girişimi ile ilgili ihtiyaçları gidermek için gereken fonu kendi dışında yer alan büyük bir kitleden temin edebilmektedir. Dolayısıyla, kitlesel fonlama ülkelerin girişimcilik ekosistemi kültürünün geliştirilmesi adına önemli katkılar sunmakta girişimcilerin kolaylıkla ve hızla kaynak temin edebilmesini sağlamaktadır (Çonkar \& Canbaz, 2018). Kitlesel fonlama platformları özellikle Amerika Birleşik Devletleri ve Avrupa Birliği ülkelerinde 2000'lerin başından beri yaygın olarak kullanılmakta; bu platformların gelişmekte olan ülkelerde kullanımı ise her geçen gün artmaktadır. Dünya Bankası'nın 2013'te yayımladığı "Gelişmiş Ülkeler için Kitlesel Fonlama Potansiyeli" raporuna göre kitlesel fonlamanın en çok teknoloji, finans ve film sektörlerinde tercih edildiği görülmektedir. Raporda kitlesel fonlamanın gelişmekte olan ülkelerin gelişmiş ülkeleri teknoloji ve finans alanlarında yakalaması için bir araç olarak kullanabileceği belirtilmiştir.

$\mathrm{Bu}$ çalışma, kitlesel fonlama başarısını etkileyen faktörlerin tespiti için kitlesel fonlama platformlarından toplanan proje bilgilerinin analizi vasitasıyla detayli bir inceleme sunmayı amaçlamaktadır. Bu amaç doğrultusunda, Türkiye ve Amerika Birleşik Devletleri'ndeki kitlesel fonlama platformlarından elde edilen teknoloji ve film sektörlerine ait başarılı ve başarısız olmuş kitlesel fonlama projelerinin verisi toplanmıştır. Kapsamlı bir literatür taraması sonucu belirlenen ve Sinyal Teorisi ile Sosyal A $\breve{g}$ Teorisi çerçevesinde incelenen değişkenler açısından proje başarısına etki eden faktörler analiz edilmekte ve bulgular tartışılmaktadır. Çalışmanın örneklemi 120 adet kitlesel fonlama projesinden oluşmakta ve Türkiye-ABD ile Teknoloji-Film olmak üzere alt kırılımlar içermektedir. Proje başarısının bağımlı değişken olarak alındığı lojistik regresyon analizleri vasıtasıyla örneklemin bütününde ve bütün potansiyel alt kırılımlarında analizler gerçekleştirilmiş, bulguların uluslararası literatürle uyumluluğu tartışılmıştır. Dolayısıyla çalışmanın bulguları ülke ve sektör özelinde de zengin bulgular ortaya koymaktadır. Çalışma, Türkiye’de kitlesel fonlama başarısını inceleyen öncül çalışmalardan biridir. Güncel literatürde kitlesel fonlama projeleri üzerine yapılan çalışmalar daha çok tanımlayıcı nitelikte olup bu çalışmadaki kapsamda bir ampirik çalışma bulunmamaktadır.

Çalışma şu şekilde organize edilmiştir: İkinci bölümde kitlesel fonlama ile ilgili temel kavramlar, aktörler ve kitlesel fonlama çeşitleri tartışılmaktadır. Üçüncü bölüm kitlesel fonlama projelerinin başarısına etki etme potansiyeli olan faktörlerin literatür incelemesi bağlamında detaylı incelenmesini ve çalışmanın hipotezlerini sunmaktadır. Dördüncü bölüm çalışmanın model tasarımını ve veri setini tartışmaktadır. Beşinci bölüm analiz sonuçlarına, 
altıncı bölüm bulguların literatür ve hipotezler çerçevesinde tartışılmasına ayrılmıştır. Yedinci bölüm sonuç bölümüdür.

\section{Kavramsal Çerçeve}

Kitlesel fonlama çeşitli girişimlere fon sağlamak için çeşitli amaçlarla oluşturulan projelerin bireylerden fon sağlamasına olanak sağlayan çağdaş bir yöntemdir. Ticari, kültürel veya sosyal projelerin kurucularının gelecekteki ürünleri veya hisseleri karşılığında birçok kişiden finansman talep etmelerine olanak tanımaktadır (Mollick, 2014). Genel olarak, kitlesel fonlama sistemi Türk kültüründeki imece usulü yardımlaşmanın internet üzerinden yirmi birinci yüzyıl şartlarına uyarlanmış haline benzetilebilir (Ünsal, 2017). Kitleler sayesinde küçük yatırımların büyük yatırımlara dönüşmesine olanak sağlamaktadır. Geleneksel finansmanla karşılaştırıldığında kitlesel fonlama yatırımcıya fiyat çeşitlendirmesi yaparak daha çok fon bulma avantajı sağlamaktadır (Belleflamme vd., 2012). Bunun yanı sıra, kitle ile kaynaklardan yararlanmayı birleştirmesi fonlama maliyetlerini azaltmaktadır (Howe, 2006).

\subsection{Kitlesel Fonlama Aktörleri}

Kitlesel fonlama sisteminde literatürde de kabul edilen üç temel aktör vardır: Fon talep eden girişimci, fon sağlayan yatırımcı ve bu iki grubu birleştiren aracı platform (Valanciene \& Jegeleviciute, 2013; Ordanini vd., 2011).

- Fon talep eden girişimci (proje sahibi), kendine ait bir iş fikri veya projesini hayata geçirmek için gerekli fonu kitlelere açık çağrıda bulunarak toplamayı amaçlayan kişi(leri) veya kuruluş(ları) ifade etmektedir. Bütün sektörlerden proje sahipleri kitlesel fonlama platformlarını kullanabilir. Bugüne kadar çoğunlukla müzik albümleri için kullanılan platformlar, sanat, yardım projeleri ve bilimsel araştırma gibi birçok alanda fon toplanılmasını sağlamıştır (Gerber vd., 2012).

- Fon sağlayan yatırımcı, geleneksel fonlamanın aksine çoğunlukla yatırım bilgisi ve geçmişi olmayan sıradan insanları ifade eder. Genellikle, platformlar üzerinden cüzi miktarlarda katkı sağlarlar. Kitlesel fonlamada fon sağlayan yatırımcı genel olarak bu kitle ile ifade edilse de bilgisi olan alanında uzman kişilerin veya melek yatırımcıların da çeşitli meblağlarda yatırımlarda bulunmasında bir engel yoktur (Ordanini vd., 2011). Kitlesel fonlama platformlarında buluşacak fon sağlayıcıları ile girişimcilerin aynı coğrafi konumda olmasına gerek bulunmamaktadır. Bu sürecin en pratik ve çekici özelliklerinden biri de bu sebeple coğrafi konuma bağlı olmamasidir (Agrawal vd., 2011).

- Kitlesel fonlama platformları, ülkeden ülkeye değişen yasal düzenlemelerin içerisinde taraflar arasındaki anlaşmayı kontrol altına yasal bir şekilde alan, sistemin işleyişi açısından önemli bir aktördür. Kitlesel fonlama platformlarında toplanan fonun aktarımı ile ilgili de farklılaşan yaklaşımlar bulunmaktadır. Platformlarda kullanılan modellerden biri "Hepsi veya hiç" modelidir. Bu model ile proje başarıya ulaşamazsa toplanan fonların tamamı fon sağlayan yatırımcılara 
Akyıldız, B. \& S. Metin-Camgöz \& K.B. Atıcı (2021), "Kitlesel Fonlama Projelerinin

Başarılarını Etkileyen Faktörler Üzerine Bir İnceleme", Sosyoekonomi, 29(50), 521-545.

geri ödenirken, "Hepsini tut" modelinde toplanan fon hedeflenen fona ulaşmasa dahi girişimciye ödenmektedir (Valanciene \& Jegeleviciute, 2014).

\subsection{Kitlesel Fonlama Modelleri}

Kitlesel fonlama modelleri fon sağlayan yatırımcının finansal getiri amacı olması ve olmamasına göre iki ana sınıfa ayrılmaktadır. Finansal getiri amacı olamayan modeller bağış temelli ve ödül temelli kitlesel fonlama modelleridir. Finansal getiri amaçlı fonlamalar ise borç temelli ve hisse temelli kitlesel fonlamalardır.

- Bağış temelli kitlesel fonlama, herhangi bir kazancı ve beklentisi olmadan başka insanlara destek vermek veya ilgisini çeken projeye fon desteği sağlamak amacıyla katkıda bulunarak sosyal motivasyon ve hayırseverlik ile bütünleşen fonlama modelidir. Bu fonlama türünde projelere destek olan fon sağlayıcılar, karşılığında herhangi bir kazanç beklememektedirler (Griffin, 2012; Gulati, 2014).

- Ödül temelli kitlesel fonlama, genellikle bir ürün veya hizmet sunan yeni bir "start-up" veya kuruluş için fon toplamak için kullanılan yaygın bir kitlesel fonlama türüdür. Ödül temelli fonlama modelinde projesi başarılı olan girişimci, yatırımcıya bunun karşılığında finansal olmayan bir ödül sunmaktadır. Bu ödüller projenin içeriğinde de yer alan müzik albümü, bir tişört veya bir teşekkür mektubu olabilmektedir. (Atsan, Erdoğan; 2015).

- Borç temelli kitlesel fonlama hem bireyler hem de işletmeler için ihtiyaç duydukları finansal desteği hızlı ve kolay bir şekilde elde etme yollarından biridir. Borçlanma temelli kitlesel fonlamada girişimciler kitlelerden borç olarak fon toplamaktadır. Bu modelde, amaçlanan projenin başarılı olmasıyla girişimci dönem sonunda borcunu faiziyle geri ödemeyi kabul etmektedir (Griffin, 2012).

- Hisse temelli fonlama fon sağlayıcıya hisse vaadi ile işlemektedir. Projeye finansal destek sağlayan yatırımcılar, proje ortağı olmak amacıyla getiri beklentisi içerisinde olmaktadırlar. Fon sağlayan yatırımcının girişimi desteklemesinin sonucunda amacı, desteklediği projenin belirli bir düzeye gelmesi ve sonrasında kendi hisselerini değer kazandıktan sonra satmak istemesidir (İstfonbul, 2018).

\section{Literatür Taraması: Kitlesel Fonlama Proje Başarısını Etkileyen Faktörler}

Akademik literatürde, sayısı çok olmasa da kitlesel fonlama projelerinin başarısını etkileyen faktörlerin belirlenmesi amacını güden çalışmalar bulunmaktadır. Bu faktörler teorik olarak Sinyal Teorisi bağlamında ele alınabilir. Sinyal Teorisi, temelde bir sosyal değişim ilişkisinde iki taraf (bireyler veya kuruluşlar) arasındaki bilgi asimetrisini azaltmakla ilgilidir (Spence, 1973; Spence, 2002). Tipik olarak, bir taraf (gönderen) bilginin iletilip iletilmeyeceğini ve nasıl iletileceğini seçmekte ve diğer taraf (alıcı) sinyali nasıl yorumlayacağına (veya görüntüleyeceğine) karar vermektedir. Kitlesel fonlama projeleri açısından sinyal gönderen proje sahibi, sinyalin alıcısı ise fon sağlayan yatırımcı olarak ele alınabilir. Wang vd. (2015)'nin kitlesel fonlama başarısına nelerin etkilediğini anlamak için gerçekleştirdiği sinyal teorisi odaklı araştırmalarında da sinyal teorisi, içerik 
oluşturuculardan yani proje sahiplerinden gelen sinyaller ve projelerden gelen sinyaller bağlamında incelenmektedir. Dolayısıyla bu bölümde, kitlesel fonlama başarısını etkileyen faktörler proje ile ilgili faktörler ve proje sahibi ile ilgili faktörler olmak üzere iki başlık altında ele alınmaktadır. Proje ile ilgili faktörler proje sinyalleri, proje sahipleri ile ilgili faktörler de proje sahibi sinyalleri olarak düşünülebilir.

Literatürde kitlesel fonlama başarısını etkileyen faktörlerin belirlenmesine yönelik çalışmalarda yer alan proje sinyallerine ilişkin değişkenler, videoya sahip olma durumu, video süresi, minimum yatırım tutarı, maksimum yatırım tutarı, ödül sayısı, hedeflenen fon miktarı, fonlama süresi ve proje açıklaması karakter uzunluğu gibi değişkenlerdir. Proje sahibi sinyalleri boyutunda ise proje sahibi hakkında bilgi olup olmaması, proje sahibinin yaşı, eğitimi, cinsiyeti, web sayfasına sahip olup olmaması ve proje sahibinin sosyal ağ büyüklüğü ile ilgili değişkenlerdir. Burada özellikle proje sahibinin sosyal ağ büyüklüğü ile ilgili değişkenler sinyal teorisinin yanı sıra kuramsal olarak Sosyal Ağ Teorisi bağlamında da incelenebilir. A $\breve{g}$ teorisinin en temel özelliği aktörler arasındaki (bireyler veya firmalar) ilişkiye odaklanmasıdır. Örneğin, bir yeniliğe sahip olacak tarafın karakteristik özelliklerini (yaş, kişilik, vb.) dikkate almak yerine ağ teorisini savunanlar, insanlar arasındaki birbirlerini etkileme süreçlerinin önemini ve başkası tarafından etkilendiklerini savunmaktadır. Böylece bir kişi iPhone gibi bir yeniliği yalnızca bu marka için doğru kişiliğe sahip olduğu için değil aynı zamanda arkadaşı da buna sahip olduğu için benimsemektedir (Borgatti vd., 2014).

\subsection{Proje ile İlgili Faktörler}

Proje sinyalleri olarak da isimlendirilebilecek bu faktörler, kitlesel fonlama platformlarında yer alan projelerin platform üzerindeki temel özellikleri ile ilgilidir. Burada yer alan faktörler ile ilintili değişkenler, kitlesel fonlama projelerinin başarısını etkileyen faktörlerin belirlenmesine yönelik çalışmalarda yaygınlıkla yer almaktadır. Aşağıda bu faktörler (değişkenler) tartışılmakta, değişkenleri proje başarısı ile ilişkisine yönelik literatüre dayalı hipotezler oluşturulmaktadır.

Video: Kitlesel fonlama platformlarında proje sayfasında yer alan videolar projenin kapsamı ve proje sahipleri hakkında bilgiler içermektedir. Petitjean (2018), girişimci ile destekçiler arasındaki bilgi asimetrilerini azaltmakla ilgilenen sinyal teorisi temelli araştırmasında proje sahiplerinin web sayfalarında video olup olmaması durumunun destekçilere verdiği sinyal kalitesini artırdığını belirtmektedir. Bununla beraber, Kunz vd. (2016)'ne göre bir videoda, proje sahibi genellikle finanse edilen ürün veya hizmeti göstermekte, bu durum finansman sürecini daha güvenilir kılmaktadır. Marom, Sade ve Gafni (2018)'nin araştırmasında projenin bulunduğu sayfada videonun bulunmasının, projenin başarısını videoya yer vermeyenlere göre \%81,4 artırdığı sonucuna varılmıştır. İncelenen çalışmaların bulgularından hareketle proje sayfasında video olup olmamasının proje başarısı üzerinde etkisine yönelik olarak aşağıdaki hipotez oluşturulmuştur: 
H1: Proje sayfasında video yer alması ile proje başarısı arasında olumlu yönde bir ilişki vardır.

Video Süresi: Geleneksel reklamcılığa bakıldığında reklam süresi, kampanyanın etkililiğini etkileyebilmektedir (Swaminathan \& Kent, 2013). Sinyal teorisinin sinyali alan karşı tarafı (yatırımcıyı) etkileme temeli olması video süresinin proje başarısı ile ilişkilendirilebileceğini göstermektedir. Drablos (2015), kitlesel fonlama projesini etkileyen faktörlerin ne olduğu sorusunu araştırırken cevap olarak video uzunluğunun ne kadar olması hakkında çeşitli cevaplar almakta ancak bunlardan sadece birkaçı aynı noktada buluşmaktadır. Ortak düşünce videoların uzunluğunun 3 dakikadan kısa olması yönündedir. $\mathrm{Bu}$ araştırmalardan hareketle bu çalışmada proje sayfasında yer alan videoların uzunluğunun (saniye) proje başarısı üzerinde etkisine yönelik olarak aşağıdaki hipotez oluşturulmuştur:

H2: Proje sayfasında yer alan videonun süresinin uzunluğu ile proje başarısı arasında olumlu yönde bir ilişki vardır.

Minimum Yatırım Tutarı: Projeye destekçiler tarafından en az ne kadar yatırılabileceğini gösteren minimum yatırım tutarı da projeye fon sağlama potansiyeli olan yatırımcılara proje ile ilgili önemli sinyal sağlamaktadır. Bu konudaki genel eğilim, proje sahiplerinin daha çok destekçi çekeceklerini düşünerek ödül miktarını düşük tutmaları yönündedir (Forbes \& Schaefer, 2017). Kıran (2013) yatırım miktarının küçük olmasının katkının yüksek olacağını belirtmektedir. Buradan hareketle, bu ters yönlü ilişkiye yönelik olarak Projelerin minimum yatırım tutarları ile proje başarısı arasında aşağıdaki hipotez oluşturulmuştur:

H3: Proje sayfasında yer alan ödülün minimum yatırım tutarı ile proje başarısı arasında olumlu yönde bir ilişki yoktur.

Maksimum Yatırım Tutarı: Kitlesel fonlama platformlarında, minimum yatırım tutarının yanı sıra maksimum yatırım tutarları ödül katmanları şeklinde görülmektedir (Kohli vd., 2016). Literatür genellikle minimum yatırım tutarı üzerinde yoğunlaşsa da maksimum yatırım tutarlarının etkisi de test edilebilir. Bu amaçla aşağıdaki hipotez oluşturulmuştur:

H4: Proje sayfasında yer alan ödülün maksimum yatırım tutarı ile proje başarısı arasında olumlu yönde bir ilişki vardır.

Ödül Sayısı: Ödül Temelli Kitlesel Fonlama, farklı sayılarda ve çeşitlerde ödüllere sahiptir. Bu ödüller teminat olarak değerlendirilmektedir. Proje başarılı sonuçlandığında bu ödüller yatırımcılara ulaştırılmaktadır. Kuppuswamy ve Bayus (2013) kitlesel fonlama platformları içerisinde proje destekçilerine verilen ödüllerin yatırımcı motivasyonu açısından önemli bir yeri olduğunu belirtmektedirler. Destekçilerin katılımının ödülün miktarı ve fon tutarı içerisindeki tutarına göre etkileneceği belirtilmiştir (Lacan \& Desmet, 2017). Diğer yandan karışıklık olmaması adına ödül sayısının çok fazla olmaması gerektiğiyle ilgili sonuçlar da elde edilmiştir (Forbes \& Schaefer, 2017). Daha basit bir ödül 
sistemi olmasının, daha az ve ilgi çekici ödülle destekçilerin ilgisini çekebileceği savunulmaktadır (Leite \& Moutinho, 2012). Ödül çeşitliliğinin proje başarısına etkisini görebilmek adına ödül sayısı ile proje başarısı arasındaki ilişkiye yönelik aşağıdaki hipotez oluşturulmuştur:

H5: Proje sayfasında yer alan ödüllerin sayısı ile proje başarısı arasında olumlu yönde bir ilişki vardır.

Hedeflenen Fon Miktarı: Proje sahiplerinin projelerini hayata geçirebilmek için kitlesel fonlama platformlarından yardım alarak ulaşmak istedikleri tutar hedeflenen fon miktarı olarak tanımlanmaktadır (Mollick, 2014). Proje sahipleri hedefledikleri fon miktarına ulaştıklarında projeleri başarılı kabul edilmektedir. Kunz vd. (2016) ödül temelli kitlesel fonlamada sinyal teorisi araştırması dikkate alınarak hedeflenen fonlama miktarı proje sinyali olarak değerlendirilmiş ve bu amaçla aşağıdaki hipotez oluşturulmuştur:

H6: Projede hedeflenen fon miktarı ile proje başarısı arasında olumlu yönde bir ilişsi vardır.

Fonlama Süresi: Fonlama süresi, bir projenin fonlamayı kitlesel fonlama platformu üzerinde kabul ettiği süre olarak tanımlanmaktadır (Mollick, 2014). Projelerin destekçilerden finansal destek alabileceği süre (gün) Kickstarter'da maksimum 60 gündür (Frydrych vd., 2014). Kunz vd. (2016), Mollick (2014) ve Claus vd. (2017) başarı ile fonlama süresi arasında negatif ilişki olduğunu rapor ederken, Cordova vd. (2015) ile Burtch vd. (2013) pozitif bir ilişki rapor etmektedir. Kitlesel fonlama proje sayfalarında yer alan başlangıç ve bitiş süreleri arasında gün sayısı üzerinden aşağıdaki hipotez oluşturulmuştur:

H7: Proje fonlama süresi ile proje başarısı arasında olumlu yönde bir ilişki vardır.

Açıklama Uzunluğu: Girişimcinin meşruiyet kazanması ve kaynaklara daha kolay erişebilmesi için hikayesini iyi inşa etmesi gerekmektedir (Lounsbury \& Glynn, 2001). Literatürde, kitlesel fonlamanın alternatif veya sosyal fayda yatırımlarını kolaylaştırdığı anlayışı yaygındır (Lehner, 2013). Bu bakış açısından meşruiyet, yatırımcıyı sosyal ve ticari hedefte birleştirecektir (Frydrych vd., 2014). Dolayısıyla, ikna edici bir yatırım hikayesi oluşturmak kitlesel fonlama faaliyetlerinin başarısında önemli bir rol oynayacaktır (Lounsbury \& Glynn, 2001). Kunz vd. (2016) ödül temelli kitlesel fonlamada sinyal teorisi araştırması dikkate alınarak proje açıklama uzunluğu kelime sayısı proje sinyali olarak analiz edilmiş ve bu amaçla aşağıdaki hipotez oluşturulmuştur:

H8: Proje açıklama uzunluğu karakter sayısı ile proje başarısı arasında olumlu yönde bir ilişki vardır.

\subsection{Proje Sahipleri ile İlgili Faktörler}

Kitlesel fonlama bağlamında proje sahipleri, projelerini veya hayata geçirmek istedikleri iş fikirlerini ticarileştirmek adına kitlelerden fon toplayan girişimcilerdir. Genel olarak, proje sahibinin veya ekibinin kitlesel fonlama platformunda proje sayfasında kişisel bilgilerinin bulunması potansiyel yatırımcılara güven ve ciddiyet vererek olumlu bir etki 
yaratmaktadır (Boeuf vd., 2014). Aşağıda, proje başarısı ile ilişkili olabilecek proje sahipleri ile ilgili kişisel faktörler tartışılmaktadır.

Proje Sahibi Hakkında Bilgi: Proje sahipleri ile ilgili öncelikli test edilmesi gereken proje sayfasında proje sahibi hakkında bilgi olup olmamasının proje başarısı üzerindeki etkisidir. Proje sahibinin veya ekibin kitlesel fonlama platformunda proje sayfasında kişisel bilgilerinin bulunması potansiyel yatırımcılara güven ve ciddiyet vererek olumlu bir etki yaratmaktadır (Boeuf vd., 2014). Kitlesel fonlama platformlarının sosyal bir çevre olarak görülmesinden dolayı proje sahipleri hakkında bilgilerin yer alması olumlu bir etki yaratacaktır (Colombo vd., 2015). Aynı şekilde Frydrych vd. (2014)'ye göre proje sahibi hakkında bilgi olması projenin yasallığını artıracak ve projenin başarılı olmasına katkı sağlayacaktır. Bu amaçla, aşağıdaki hipotez oluşturulmuştur:

H9: Proje sayfasında proje sahibi hakkında bilgi olmasının proje başarısını olumlu yönde bir ilişki vardır.

Proje Sahibinin Cinsiyeti: Kitlesel fonlama ile fonlanan projeleri inceleyen çalışmalar projeye fonlama ile destek veren yatırımcıların projeyi yürüten kişilerin bilgilerinden etkilendiklerini göstermektedir (Şahinoğlu, 2019). Kadın kitlesel fonlama proje sahipleri veya projeyi erkek ve kadın beraber yönetenlerin, sadece erkek proje sahiplerine göre daha başarılı oldukları görülmüştür (Frydrych vd., 2014). Diğer taraftan bazı çalışmalar projenin desteklenme durumunun proje sahibi cinsiyetine bağlı olmadığını savunmaktadır (Levin, 2015; Marom vd., 2018). Proje sahibinin cinsiyetinin kadın olmasının proje başarısını etkilediği yönünde çalışmalar olsa da cinsiyetin proje başarısında etkisiz kaldığını gösteren birçok çalışma bulunmaktadır. Araştırmalardan hareketle proje sahibinin cinsiyetinin proje başarısı üzerinde etkisinin testi amacıyla aşağıdaki hipotez oluşturulmuştur:

H10: Proje sahibinin kadın olması veya ekibi içerisinde kadın olması ile proje başarısı arasında olumlu yönde bir ilişki vardır.

Proje Sahibinin Yaşı: Levin (2015), bir kitlesel fonlama projesine destekçiler tarafından destek verilmesi kararının proje sahibinin yaşı gibi özelliklerden etkilenmediğini ortaya koymaktadır. Alois (2014)'e göre kitlesel fonlamayı kullanan insanlar ortalama 35 yaşındadır. Literatürde, girişimcilerin yaşının kitlesel fonlama başarısına etkisi yönünde yeterince çalışma bulunmasa da genel görüş proje başarısını etkilemeyeceği şeklindedir. İlişkinin test edilmesi amacıyla aşağıdaki hipotez oluşturulmuştur:

\section{H11: Proje sahibi yaşı ile proje başarısı arasında olumlu yönde bir ilişki vardır.}

Proje Sahibinin Ĕgitim Durumu: Genel anlamda, proje sahiplerinin eğitim durumundaki farklılıkların da kitlesel fonlama proje başarısına anlamlı bir etkisi bulunmamıştır (Marom vd., 2018). Ancak, profesyonel yatırımcılar için eğitim durumu gibi özellikli bilgilerin yatırım kararlarını etkilemede önemli bir etkisi olduğu tespit edilmiştir (Audretsch vd., 2012). Girişimci eğitim durumunun kitlesel fonlama proje başarısına etkisi 
üzerinde net sonuçlar olmamasıyla beraber ilişkinin test edilmesi adına aşağıdaki hipotez oluşturulmuştur:

\section{H12: Proje sahibinin eğitim durumu ile proje başarısı arasında olumlu yönde bir ilişsi} vardir.

Proje Sahibinin Harici Web Sayfası: Drablos (2015), proje sahiplerinin insanların iletişimde kalacağı, güncellemeleri alacağı, resimleri görebileceği ve proje ayrıntılarını görebilecekleri kendilerine ait web sayfalarının kurulması gerektiğinden bahsetmektedir. Proje sayfasına eklenen web sayfaları kitlesel fonlama proje sonucuyla pozitif bir ilişki vermektedir (Skirnevsky vd., 2017). Proje harici web sitelerini “daha fazla bilgi” değişkeni olarak kaydeden bir çalışma ise dış bağlantıların önemli sonuçlar vermediğini belirtmiştir (Colombo vd., 2014). Proje sayfasında proje sahibinin harici bir web sitesine sahip olmasının proje başarısı üzerinde etkisini belirlemek adına aşağıdaki hipotez oluşturulmuştur:

H13: Proje sahibinin harici web sayfasına sahip olma durumu ile proje başarısı arasında olumlu yönde bir ilişki vardır.

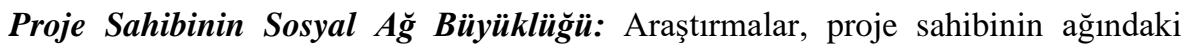
bağlantı sayısının, projelerin topladığı fon başarısıyla olumlu bir ilişkisi olduğunu göstermektedir (Hui vd., 2014; Mollick, 2014). Ağın genişletilmesi konusunda yapılan diğer çalışmalar, sadece miktarın değil, aynı zamanda proje sahibi ile proje destekçisi arasındaki güçlü ve zayıf bağların da projenin başarısı için önemli olduğuna işaret ederek ilerlemektedir (Bakshy vd., 2012). Çevrim içi ortamlar, kitlesel fonlama projelerinin potansiyel destekçileri tarafından projenin varlığından haberdar olmaları ve aktif bir şekilde fonlamalarına olanak sağlamaktadır (Şahinoğlu, 2019). Borst vd. (2017) proje sahibinin yakınları dışında kalan proje destekçileri ile Instagram, Twitter ve Linkedin gibi sosyal medya platformları üzerinden tanıtılma başarısı ilişkilendirmiştir. Aynı şekilde, Mollick (2014), sadece proje sahibi yakınları ile hedeflenen fon miktarına ulaşılamayacağını düşünmüş ve başka kişilere de ulaşılması gerektiğini vurgulamıştır. Sosyal ağlar yardımıyla kitlesel fonlama platformlarının tanıtılması fon talep edenden fon sağlayana doğru farkındalığı artırarak potansiyel destekçileri artırmaktadır. Proje sahibi çevrim içi platformlarından projesinin tanıtımını yaparak daha çok kişiye ulaşmasını sağlayarak projesinin güçlenmesini sağlamaktadır (Lu vd., 2014). Literatürde proje sahiplerinin çevrim içi platformlarının bulunmasının projelerin başarısını olumlu etkilediği görülmektedir. Dolayısıyla, proje sahiplerinin çevrim içi platformlarda bulunan bağlantı (takipçi) sayılarının proje başarısına etkisi de değerlendirilmesi gereken bir faktördür. Araştırmalardan hareketle proje sayfasında proje sahibinin Instagram, Twitter veya Linkedin hesabına sahip olup olmaması ile toplam bağlantı sayılarının proje başarısı üzerinde etkisinin analizi amacıyla aşağıdaki hipotezler oluşturulmuştur:

H14: Proje sahibi Instagram, Twitter veya Linkedin hesabina sahip olma durumu ile proje başarısı arasında olumlu yönde bir ilişki vardır. 
H15: Proje sahibi Instagram, Twitter ve Linkedin hesabı bağlantı sayısı ile proje başarısı arasında olumlu yönde bir ilişki vardır.

\section{Veri Seti ve Yöntem}

Kitlesel fonlama projelerinin başarısını etkileyen faktörleri belirlemek amacıyla literatür taramasına dayandırılarak bir önceki bölümde verilen hipotezler oluşturulmuştur. Bu hipotezleri test etmek amacıyla gelişmiş ülkeleri temsilen kitlesel fonlamanın en yaygın kullanıldığı ülke olan Amerika Birleşik Devletleri'nden (ABD), gelişmekte olan ülkeleri temsilen ise Türkiye'den sonuca ulaşmış bir kitlesel fonlama proje örneklemi seçilmiştir. Örneklem belirlenirken Türkiye'de en yaygın kullanılan kitlesel fonlama modeli olan Ödül Temelli Kitlesel Fonlama modeli esas alınmıştır. Her bir ülkeden 60 projenin yer aldığ1 örneklem, sektör olarak her iki ülkede de kitlesel fonlamanın en yaygın kullanıldığı sektörler olan film ve teknoloji endüstrilerinden eşit sayıda proje içermektedir. Örneklemde yer alan her bir ülkenin her bir sektöründe eşit sayıda başarılı ve başarısız proje yer almaktadır. Örneklem toplamda 120 projeden oluşmaktadır. Ülke, sektör ve başarı durumu açısından örneklem büyüklüğü dağılımı Tablo 1'de özetlenmektedir.

Tablo: 1

\section{Örneklem Büyüklükleri}

\begin{tabular}{|c|c|c|c|}
\hline Ülke & Sektör & Proje Başarısı & Proje Sayısı \\
\hline \multirow{4}{*}{ Türkiye } & \multirow{2}{*}{ Film } & Başarılı & 15 \\
\hline & & Başarısız & 15 \\
\hline & \multirow{2}{*}{ Teknoloji } & Başarılı & 15 \\
\hline & & Başarısız & 15 \\
\hline \multirow{5}{*}{$\mathrm{ABD}$} & \multirow{2}{*}{ Film } & Başarılı & 15 \\
\hline & & Başarısız & 15 \\
\hline & \multirow{3}{*}{ Teknoloji } & Başarılı & 15 \\
\hline & & Başarısız & 15 \\
\hline & & Toplam & 120 \\
\hline
\end{tabular}

Örneklemde yer alan kitlesel fonlama projeleri için hipotezlere uygun olarak belirlenen değişkenlere ait veriler toplanmıştır. ABD örneklemi için tüm veriler Dünya'da en popüler kitlesel fonlama platformu olan Kickstarter platformundan toplanırken, Türkiye için en yaygın kullanılan kitlesel fonlama platformları olan Fongogo, Crowdfon, Reward Fon Bulucu, Arı Kovanı platformlarından yararlanılmıştır.

Bağımlı değişken olarak kitlesel fonlama projesinin başarıya ulaşması 0 veya 1 değerini alan ikili bir değişken olarak belirlenmiştir. Bağımlı değişkenin ikili yapısından hareketle hipotezler ikili lojistik regresyon kullanılarak test edilmiştir. Bağımsız değişkenler ise hipotezlere uygun olarak tespit edilmiştir. Belirlenen bağımsız değişkenler Tablo 2'de listelenmektedir.

Belirlenen bağımsız değişkenlerden proje sahiplerinin harici bir web sitesine sahip olup olmaması (WEB), projelerin ödül sayısı (ODUL), projelerin fonlama süresi (SURE) ve proje sahiplerinin sosyal medya hesabına sahip olup olmaması (SOSMED) değişkenleri kontrol değişkenleri olarak kabul edilmiştir. Bağımsız değişkenlere ait tanımlayıcı istatistikler Tablo 3 'te sunulmaktadır. 
Tablo: 2

Bağımsız Değişkenler

\begin{tabular}{|c|l|l|}
\hline \multicolumn{1}{|c|}{ Proje ile İlgili Değişkenler } & \multicolumn{1}{|c|}{ Kısaltma } \\
\hline $\mathbf{1}$ & Videoya sahip olma /olmama & VID \\
\hline $\mathbf{2}$ & Video süresi (sn) & VIDSURE \\
\hline $\mathbf{3}$ & Minimum yatırım tutarı & MINYT \\
\hline $\mathbf{4}$ & Maksimum yatırım tutarı & MAXYT \\
\hline $\mathbf{5}$ & Ödül sayısı & ODUL \\
\hline $\mathbf{6}$ & Hedeflenen fon miktarı & HEDEF \\
\hline $\mathbf{7}$ & Fonlama süresi (gün) & SURE \\
\hline $\mathbf{8}$ & Açıllama uzunluğu karakter sayısı & ACIKKAR \\
\hline $\mathbf{9}$ & Proje sahibi hakkında bilgi olup olmaması & SAHIPBILGI \\
\hline $\mathbf{1 0}$ & Proje sahibi cinsiyeti & CINS \\
\hline $\mathbf{1 1}$ & Proje sahibi yaşı & YAS \\
\hline $\mathbf{1 2}$ & Proje sahibi eğitim düzeyi & EGTM \\
\hline $\mathbf{1 3}$ & Web sitesine sahip olma /olmama & WEB \\
\hline $\mathbf{1 4}$ & Sosyal medya hesabına sahip olma / olmama & SOSMED \\
\hline $\mathbf{1 5}$ & Sosyal medya bağlantı sayısı & SOSMEDNET \\
\hline
\end{tabular}

Tablo: 3

Bağımsız Değiş̧kenlere Ait Tanımlayıcı İstatistik Tablosu

\begin{tabular}{|c|c|c|c|c|c|c|}
\hline & & Ortalama & Standart Sapma & Minimum & Maksimum & Değişken Tipi \\
\hline 1 & VID & 0,80 & 0,40 & 0 & 1 & Kukla \\
\hline 2 & VIDSURE & 134,68 & 196,81 & 0 & 1.620 & Metrik \\
\hline 3 & MINYT & 12,43 & 27,57 & 0,67 & 198 & Metrik \\
\hline 4 & MAXYT & 2.170 & 4.372 & 1 & 30.000 & Metrik \\
\hline 5 & ODUL & 8,34 & 6,81 & 1 & 50 & Metrik \\
\hline 6 & HEDEF & 30.018 & 101.606 & 93,34 & 1.000 .000 & Metrik \\
\hline 7 & SURE & 42,54 & 15,43 & 15 & 89 & Metrik \\
\hline 8 & ACIKKAR & 5.161 & 4.581 & 0 & 26.76 & Metrik \\
\hline 9 & SAHIPBILGI & 0,71 & 0,46 & 0 & 1 & Kukla \\
\hline 10 & CINS & 0,23 & 0,51 & 0 & 2 & Kukla \\
\hline 11 & YAS & 33,19 & 12,60 & 11 & 61 & Metrik \\
\hline 12 & EGTM & 15,52 & 3,73 & 8 & 23 & Metrik \\
\hline 13 & WEB & 0,54 & 0,50 & 0 & 1 & Kukla \\
\hline 14 & SOSMED & 0,70 & 0,46 & 0 & 1 & Kukla \\
\hline 15 & SOSMEDNET & 11.712 & 92.029 & 0 & 1.000 .000 & Metrik \\
\hline
\end{tabular}

Belirlenen kontrol değişkenleri öncüllenerek diğer bağımsız değişkenler modellere eklenip çıkarılarak anlamlılığı yüksek lojistik regresyon modelleri oluşturulmuştur. Verisi toplanan tüm projelerin yanı sıra verinin alt örneklemleri ile de analizler gerçekleştirilerek ülkeler, sektörler ve ülke-sektör kombinasyonları bazında da sonuçlar üretilmiştir. Kurulan modellerin içerdiği değişkenler ve ele aldıkları örneklemler Tablo 4 'te gösterilmektedir. 9 ayrı örneklem kategorisinde 19 ayrı lojistik regresyon modeli kurularak kitlesel fonlama proje başarısını etkileyen faktörler hem tüm örneklem hem de örneklemin alt kırılımları açısından incelenmiştir. Örneklemin tamamı ile yapılan analizlerin haricinde projeler ülkeler (Türkiye ve ABD), sektörler (Film ve Teknoloji) ve sektör-ülke kombinasyonları (TürkiyeFilm, Türkiye-Teknoloji, ABD-Film ve ABD-Teknoloji) olarak sınıflanarak bu alt örneklemlerde de analizler gerçekleştirilmiştir.

Tablo 4'te görüldüğü üzere belirlenen kontrol değişkenleri (WEB, ODUL, SURE ve SOSMED) modellerde en yaygın yer alan değişkenlerdir. Çeşitli örneklemlerde bu değişkenlere yeni bağımsız değişkenler aşama aşama eklenerek, her aşamada modellerin anlamlılığı gözlenmiştir (Burada bahsedilen modelin anlamlılığıdır, yüksek anlamlılıktaki bir modelde bazı değişkenlerin bağımlı değişkenle anlamlı bir ilişkisi bulunamayabileceği 
unutulmamalıdır). Model anlamlılığının yeterli düzeyde görüldüğü noktada model bulguları kaydedilerek tablolaştırılmıştır. Bu bulgular bir sonraki bölümde tartışılmaktadır.

Tablo 4'te sunulan modellerde yer alan değişkenler incelendiğinde çalışma başında belirlenen 6 değişkenin anlamlı modellerin hiçbirinde yer almadığı (bütün örneklemler açısından) görülmektedir. Bu değişkenler herhangi bir şekilde modellere eklendiğinde modelin anlamlılığını ciddi seviyede düşürmekte olduğu dolayısıyla, kitlesel fonlama projelerinin başarısına yönelik modellerin anlamlılığına herhangi bir katkı yapmadığı tespit edilmiştir. Bu değişkenler, proje sayfasında yer alan video süresi (VIDSURE), proje sahibi cinsiyeti (CINS), hedeflenen fon miktarı (HEDEF), proje sahibi eğitim durumu (EGTM), proje sahibi sosyal medya bağlantı sayıları (SOSMEDNET) ve proje sahibi yaşı (YAS) değişkenleridir.

\section{Tablo: 4}

\section{Proje Başarısını Etkileyen Faktörlerin Test Edildiği Modellere İliş̧kin Açıklamalar}

\begin{tabular}{|c|l|l|}
\hline Model & \multicolumn{1}{|c|}{ Örneklem } & \multicolumn{1}{|c|}{ Bağımsız Değisskenler } \\
\hline $\mathbf{1}$ & Tüm Veri & WEB-ODUL-SURE-SOSMED \\
\hline $\mathbf{2}$ & Tüm Veri & WEB-ODUL-SURE-SOSMED-ACIKKAR \\
\hline $\mathbf{3}$ & Tüm Veri & WEB-ODUL-SURE-SOSMED-ACIKKAR-MINYT-MAKSYT \\
\hline $\mathbf{4}$ & Tüm Veri & WEB-ODUL-SURE-SOSMED-ACIKKAR-MINYT-MAKSYT-SAHIPBILGI \\
\hline $\mathbf{5}$ & TR & WEB-ODUL-SURE-SOSMED \\
\hline $\mathbf{6}$ & TR & WEB-ODUL-SURE-SOSMED-SAHIPBILGI \\
\hline $\mathbf{7}$ & TR & WEB-ODUL-SURE-SOSMED-ACIKKAR \\
\hline $\mathbf{8}$ & ABD & WEB-ODUL-SURE \\
\hline $\mathbf{9}$ & ABD & WEB-ODUL-SURE-MINYT-MAKSYT \\
\hline $\mathbf{1 0}$ & Film & WEB-ODUL-SURE \\
\hline $\mathbf{1 1}$ & Film & WEB-ODUL-SURE-MINYT \\
\hline $\mathbf{1 2}$ & Film & WEB-ODUL-SURE-MINYT-VID \\
\hline $\mathbf{1 3}$ & Teknoloji & WEB-ODUL-SURE \\
\hline $\mathbf{1 4}$ & Teknoloji & WEB-ODUL-SURE-SAHIPBILGI \\
\hline $\mathbf{1 5}$ & TR-Film & WEB-SURE-VID \\
\hline $\mathbf{1 6}$ & TR-Film & WEB-SURE-VID-MINYT-MAKSYT \\
\hline $\mathbf{1 7}$ & TR-Teknoloji & SAHIPBILGI-MINYT-MAKSYT \\
\hline $\mathbf{1 8}$ & ABD-Film & ODUL-SURE-SOSMED \\
\hline $\mathbf{1 9}$ & ABD-Teknoloji & ODUL-SAHIPBILGI-MINYT-MAKSYT \\
\hline
\end{tabular}

Not: TR: Türkiye, ABD: Amerika Birleşik Devletleri.

\section{Bulgular}

\section{1. Örneklemin Tamamı için Bulgular}

Yapılan analizlerde öncelikle toplanan örneklemde yer alan tüm projeler (120 adet, bkz. Tablo 1) dört ayrı modelde incelenmiştir. Bu analizin bulguları Tablo 5'te sunulmaktadir.

Tablo 5'te yer alan -2 Log Likelihood değerlerine göre dört modelin de anlamlı sonuçlar ürettiği görülmektedir (Model 1: -63,2157; $P=0,0001$, Model 2: -60,0780; $P=0,0000$, Model 3: 55,2503; $P=0,0000$, Model 4: $-52,9983 ; P=0,0000)$. Hosmer ve Lemeshow test değerlerinin anlamlı çıkmaması (Model 1: $P=0,6576 ; p>0,05$; Model 2: $P=0,1962 ; p>0,05$; Model 3: $P=0,3410 ; p>0,05$; Model 4: $P=0,7930 ; p>0,05)$, model-veri uyumunun yeterli düzeyde olduğu anlamına gelmektedir (Çokluk, 2010). 
Model 1'de yer alan web sitesine sahip olma (WEB), ödül sayısı (ODUL) ve sosyal medya hesaplarına sahip olma durumu (SOSMED) değişkenleri proje başarısı bağımlı değişkenini pozitif yönde etkilemektedir. Fonlama süresi (SURE) ile proje başarısı arasında anlamlı bir ilişki görülmemektedir. Anlamlı olduğu kabul edilen Model 1 incelendiğinde modelin \%67,89 oranla doğru tahmin yaptığ 1 görülmektedir. Tablo 5'te Model 1 için verilen katsayı değerleri incelendiğinde diğer değişkenlerin sabit tutulduğu varsayılarak web sitesine sahip olma durumunun (WEB) proje başarısı ihtimalini 1,13 kat artırdığ görülmektedir. Ödül sayısı (ODUL) değişkeninin bir birim artırılması durumunda projenin başarı ihtimalinin ,102 kat arttığı görülmektedir. Sosyal medya hesaplarına sahip olma durumunda ise (SOSMED) proje başarısı ihtimalinin ,907 kat arttığı görülmektedir.

Model 2'de yer alan web sitesine sahip olma (WEB), sosyal medya hesaplarına sahip olma durumu (SOSMED) ve açıklama uzunluğu karakter sayısı (ACIKKAR) bağımsız değişkenleri proje başarısı bağımlı değişkenini pozitif yönde etkilemektedir. Bu modelde, ödül sayısı (ODUL) ve fonlama süresi (SURE) ile proje başarısı arasında anlamlı bir ilişki görülmemektedir. Açıklama karakter uzunluğunun modele girmesi ödül sayısı değişkeninin anlamlılığını etkilemektedir. Modelin \%72,22 oranla doğru tahmin yaptığı görülmektedir. Tablo 5'te Model 2 için verilen katsayı değerlerini incelediğimizde diğer değişkenlerin sabit tutulduğu varsayılarak web sitesine sahip olma durumunun (WEB) proje başarısı ihtimalini 1,08 kat artırdığı görülmektedir. Sosyal medya hesaplarına sahip olma durumunun (SOSMED) proje başarısı ihtimalinin ,901 kat arttığı görülmektedir. Açıklama uzunluğu karakter sayısı (ACIKKAR) değişkeninin bir birim artırılması durumunda proje başarısı ihtimalinin ,709 kat arttığı görülmektedir.

Model 3 bulgularına göre web sitesine sahip olma (WEB), ödül sayısı (ODUL), sosyal medya hesaplarına sahip olma durumu (SOSMED), açıklama uzunluğu karakter sayısı (AUKS) ve minimum yatırım tutarı (MINYT) değişkenleri proje başarısı bağımlı değişkenini pozitif yönde etkilemektedir. Maksimum yatırım tutarı (MAKSYT) değişkeni proje başarısı bağımlı değişkenini negatif yönde etkilemektedir. Fonlama süresi (SURE) ile proje başarısı arasında anlamlı bir ilişki görülmemektedir. Modelin \%75,93 oranla doğru tahmin yaptığı gözlenmiştir. Diğer değişkenlerin sabit tutulduğu varsayılarak web sitesine sahip olma durumunun (WEB) proje başarısı ihtimalini 1,22 kat artırdığ görülmektedir. Ödül sayısı (ODUL) değişkeninin bir birim artırılması durumunda proje başarısı ihtimalinin ,202 kat arttığı görülmektedir. Sosyal medya hesaplarına sahip olma durumunun (SOSMED) değişkeninin proje başarısı ihtimalinin 1,04 kat arttığı görülmektedir. Açıklama uzunluğu karakter sayısı (ACIKKAR) değişkeninin bir birim artırılması durumunda proje başarısı ihtimalinin ,611 kat arttığ 1 görülmektedir. Minimum yatırım tutarı (MINYT) değişkeninin bir birim artırılması durumunda proje başarısı ihtimalinin ,642 kat arttığı görülmektedir. Maksimum yatırım tutarı (MAKSYT) değişkenindeki bir birimlik artışın $(1-(-, 40=1,40)$ proje başarısı ihtimalinde \%140’lık düşüşe neden olduğu görülmektedir.

Model 4'te yer alan web sitesine sahip olma (WEB), ödül sayısı (ODUL), minimum yatırım tutarı (MINYT) ve proje sahibi hakkında bilgi (SAHIPBILGI) değişkenleri proje başarısı bağımlı değişkenini pozitif yönde etkilemektedir. Maksimum yatırım tutarı 
(MAKSYT) değişkeni proje başarısı bağımlı değişkenini yine negatif yönde etkilemektedir. Model 4'te fonlama süresi (SURE), sosyal medya hesaplarına sahip olma durumu (SOSMED) ve açıklama uzunluğu karakter sayısı (ACIKKAR) ile proje başarısı arasında anlamlı bir ilişki görülmemektedir. Modelin \%76,85 oranla doğru tahmin yaptığ1 görülmektedir. Web sitesine sahip olma durumunun (WEB) proje başarısı ihtimalinin 1,07 kat arttığı görülmektedir. Ödül sayısı (ODUL) değişkeninin bir birim artırılması durumunda proje başarısı ihtimalinin ,189 kat arttığı görülmektedir. Minimum yatırım tutarı (MINYT) değişkeninin bir birim artırılması durumunda proje başarısı ihtimalinin ,649 kat arttığ1 görülmektedir. Maksimum yatırım tutarı (MAKSYT) değişkenindeki bir birimlik artışın (1$(-, 455)=1,455)$ proje başarısı ihtimalinde \%146'lık düşüşe neden olduğu görülmektedir. Proje sahibi hakkında bilgi olmasının ise (SAHIPBILGI) proje başarısı ihtimalinin 1,31 kat arttı̆̆ görülmektedir.

Tüm örneklemin kullanıldığı modeller incelendiğinde proje sahibinin harici web sitesine sahip olması durumunun tüm modellerde proje başarısını olumlu ve anlamlı şekilde etkilediği gözlenmekte, fonlama süresi değişkeninin ise proje başarısı ile anlamlı bir ilişkisi olmadığı göze çarpmaktadır.

\section{Tablo: 5}

\section{Örneklemin Tamamından Elde Edilen Lojistik Regresyon Model Sonuçları}

\begin{tabular}{|c|c|c|c|c|}
\hline & Model 1 & Model 2 & Model 3 & Model 4 \\
\hline Örneklem & Tüm Veri & Tüm Veri & Tüm Veri & Tüm Veri \\
\hline-2 Log Likelihood & $-63,2157$ & $-60,0780$ & $-55,2503$ & $-52,9983$ \\
\hline Pseudo R2 & 0,1571 & 0,1925 & 0,2574 & 0,2876 \\
\hline Olasıllk > Ki-Kare (P değeri) & 0,0001 & 0,0000 & 0,0000 & 0,0000 \\
\hline Hosmer - Lemeshow Ki-Kare & 5,91 & 11,10 & 9,02 & 4,66 \\
\hline Serbestlik Derecesi & 4 & 5 & 7 & 8 \\
\hline Hosmer - Lemeshow Anlamlılık & 0,6576 & 0,1962 & 0,3410 & 0,7930 \\
\hline Doğruluk Yüzdesi (\%) & 67,89 & 72,22 & 75,93 & 76,85 \\
\hline \multicolumn{5}{|l|}{ Katsayı (B) } \\
\hline Sabit (c) & $-2,21 * *$ & $-8,09 * * *$ & $-7,50 * *$ & $-7,69 * *$ \\
\hline WEB & $1,13 * *$ & $1,08 * *$ & $1,22 * *$ & $1,07 * *$ \\
\hline ODUL &, $102 * *$ &, 064 &, $202 * *$ &, $189 * *$ \\
\hline SURE &,- 002 &, 007 &, 015 &, 015 \\
\hline SOSMED & ,907* & ,901* & $1,04 *$ & ,615 \\
\hline ACIKKAR_L & & ,709** &, $611 *$ & ,618 \\
\hline MINYT_L & & &, $642 * *$ &, $649 * *$ \\
\hline MAKSYT_L & & &,$- 400 *$ &,$- 455 * *$ \\
\hline SAHIPBILGI & & & & $1,31^{* * *}$ \\
\hline
\end{tabular}

\section{2. Ülke Bulguları}

Analizin bir sonraki aşamasında ülke örneklemleri ayıklanarak projeler yer aldıkları ülke örneklemleri içinde değerlendirilmiştir. Her bir ülke örnekleminde 60 adet proje bulunmaktadır (bkz. Tablo 1). Analizin bu bölümünde, Türkiye örneklemi için üç, ABD örneklemi için ise iki ayrı modelle test yapılmıştır. Analiz sonuçları Tablo 6'da sunulmaktadır.

Tablo 6'da yer alan -2 Log Likelihood değerlerine göre beş modelin de anlamlı sonuçlar ürettiği görülmektedir (Model 5: -28,5152; $P=0,0777$, Model 6: -24,7389; 
$P=0,0070$, Model 7: -25,9874; $P=0,0289$, Model 8: -27,8166; $P=0,0000 ;$ Model 9: 23,2338; $P=0,0000$ ). Hosmer ve Lemeshow test değerlerinin anlamlı çıkmaması (Model 5: $P=0,3548$; $p>0,05$; Model 6: $P=0,1440 ; p>0,05$; Model 7: $P=0,8632 ; p>0,05$; Model 8: $P=0,2997 ; p>0,05$; Model 9: $P=0,2236 ; p>0,05)$, model-veri uyumunun yeterli düzeyde olduğu anlamına gelmektedir (Çokluk, 2010). Türkiye örneklemi modellerinin tahmin yüzdeleri \%61,22 ile \%75 arasında değişirken ABD örneklemleri için kurulan modellerde bu oran \%80'dir.

Türkiye örneklemi için kurulan Model 5'te yalnızca fonlama süresi (SURE) ve sosyal medya hesabına sahip olma (SOSMED) değişkenleri proje başarısı ile düşük düzeyde anlamlı pozitif bir ilişkiye sahiptir $(p<0.10)$. Türkiye örneklemine ait bir diğer model olan Model 6'da yalnızca proje sahibi ile ilgili bilgi olması değişkeni (SAHIPBILGI) proje başarısı ile anlamlı ve pozitif bir ilişkiye sahiptir. Türkiye için proje sayfasında proje sahibi ile ilgili bulunması proje başarı olasılığını neredeyse 3 kat artırmaktadır. Türkiye örneklemi ile kurulan son model olan Model 7'de ise fonlama süresi (SURE) ve sosyal medya hesabına sahip olma (SOSMED) proje başarısı ile pozitif yönlü anlamlı bir ilişkiye sahiptir.

ABD örneklemi için kurulan modellerin Türkiye örneklemi için kurulan modellere kıyasla tahmin gücü daha yüksek bulunmuştur. Yalnızca web sitesine sahip olma (WEB), ödül sayısı (ODUL) ve fonlama süresi (SURE) değişkenlerinin ele alındığı Model 8 ' de WEB ve SURE değişkenlerinin proje başarısı ile anlamlı ilişkisi olduğu tespit edilmiştir. Fonlama süresinin ilişkisi ters yönlüdür. $\mathrm{Bu}$ modele minimum ve maksimum yatırım tutarı değişkenleri (MINYT ve MAKSYT) eklendiğinde ise bütün değişkenlerin proje başarısı ile anlamlı bir ilişkiye sahip oldukları gözlenmiştir. Maksimum yatırım tutarı ve proje başarısı ilişkisi daha önceki modellerde olduğu gibi ters yönlüdür.

\section{Tablo: 6}

\section{Ülke Örneklemlerinden Elde Edilen Lojistik Regresyon Model Sonuçları}

\begin{tabular}{|c|c|c|c|c|c|}
\hline & Model 5 & Model 6 & Model 7 & Model 8 & Model 9 \\
\hline Örneklem & TR & TR & TR & ABD & ABD \\
\hline -2 Log Likelihood & $-28,5152$ & $-24,7389$ & $-25,9874$ & $-27,8166$ & $-23,2338$ \\
\hline Pseudo R2 & 0,1285 & 0,2439 & 0,1935 & 0,3312 & 0,4413 \\
\hline Olasılık > Ki-Kare (P değeri) & 0,0777 & 0,0070 & 0,0289 & 0,0000 & 0,0000 \\
\hline Hosmer - Lemeshow Ki-Kare & 8,85 & 12,26 & 3,93 & 9,53 & 10,63 \\
\hline Serbestlik Derecesi & 4 & 5 & 5 & 3 & 5 \\
\hline Hosmer - Lemeshow Anlamlılık & 0,3548 & 0,1440 & 0,8632 & 0,2997 & 0,2236 \\
\hline Doğruluk Yüzdesi (\%) & 61,22 & 69,39 & 75,00 & 80,00 & 80,00 \\
\hline \multicolumn{6}{|l|}{ Katsayı (B) } \\
\hline Sabit (c) & $-4,51 * *$ & $-4,13$ & $-10,65^{* *}$ & 622 & 1,39 \\
\hline WEB & ,737 &, 196 &, 884 & 2,07 *** & $2,39 * * *$ \\
\hline ODUL &,- 044 &,- 277 &,- 179 &, 092 &, $225^{* *}$ \\
\hline SURE &, $043^{*}$ &, 04 &, $055 * *$ &,$- 082 * *$ &,$- 084 * *$ \\
\hline SOSMED & $2,28 *$ & 1,54 & $2,29 *$ & & \\
\hline SAHIPBILGI & & $2,81 * *$ & & & \\
\hline ACIKKAR_L & & & ,799 & & \\
\hline MINYT_L & & & & &, $663 * *$ \\
\hline MAKSYT_L & & & & &,$- 513 * *$ \\
\hline
\end{tabular}

Not: TR: Türkiye, ABD: Amerika Birleșik Devletleri, ${ }^{* * *} p<0,01 ; * * p<0,05 ; * p<0,10$.

Türkiye örnekleminin ele alındığı modellerde (Model 5-7) web sitesine sahip olma (WEB) değişkeninin hiçbir modelde proje başarısı ile anlamlı bir ilişkisi gözlenmemektedir. 
Bunun aksine ABD için kurulan her iki modelde de bu değişkenin bağımlı değişken olan proje başarısı ile pozitif yönde anlamlı bir ilişkisi bulunmaktadır. Ödül sayısı (ODUL) değişkeninin de Türkiye örnekleminde kurulan hiçbir modelde proje başarısı ile anlamlı bir ilişkisi gözlenmemektedir. Bu değişkenin yalnızca ABD örneklemi için kurulan Model 9'da proje başarısı ile pozitif yönlü bir ilişkisi olduğu tespit edilmiştir.

\subsection{Sektör Bulguları}

Analizin bir sonraki aşaması toplanan verinin sektörler bazında gruplanarak film ve teknoloji sektörleri özelinde sonuçlar üretilmesi olmuştur. Analizin bu bölümünde, Film sektörü örneklemi için üç, Teknoloji sektörü örneklemi için ise iki ayrı modelle test yapılmıştır. Analiz sonuçları Tablo 7'de sunulmaktadır.

Tablo 7'de yer alan -2 Log Likelihood değerlerine göre beş modelin de anlamlı sonuçlar ürettiği görülmektedir (Model 10: -32,9594; $P=0,0006$, Model 11: -30,0340; $P=0,0001$, Model 12: 26,6894 ; $P=0,0000$, Model 13: 23,$1679 ; P=0,0003$; Model 14: 17,5722; $P=0,0000$ ). Hosmer ve Lemeshow test değerlerinin anlamlı çıkmaması (Model 10: $P=0,4753 ; p>0,05$; Model 11: $P=0,8901 ; p>0,05$; Model 12: $P=0,7239 ; p>0,05$; Model 13: $P=0,7906 ; p>0,05$; Model 14: $P=0,7641 ; p>0,05)$, model-veri uyumunun yeterli düzeyde olduğu anlamına gelmektedir (Çokluk, 2010). Film sektörü örneklemi modellerinin tahmin yüzdeleri \%66,67 ile \%78,33 arasında değişirken ABD örneklemleri için kurulan modellerde bu oran $\% 75,51$ ve $\% 79,59$ 'dur.

\section{Tablo: 7}

\section{Sektör Örneklemlerinden Elde Edilen Lojistik Regresyon Model Sonuçları}

\begin{tabular}{|c|c|c|c|c|c|}
\hline & Model 10 & Model 11 & Model 12 & Model 13 & Model 14 \\
\hline Örneklem & Film & Film & Film & Teknoloji & Teknoloji \\
\hline -2 Log Likelihood & $-32,9594$ & $-30,0340$ & $-26,6894$ & $-23,1679$ & $-17,5722$ \\
\hline Pseudo R2 & 0,2075 & 0,2778 & 0,3583 & 0,2919 & 0,4629 \\
\hline Olasılık > Ki-Kare (P değeri) & 0,0006 & 0,0001 & 0,0000 & 0,0003 & 0,0000 \\
\hline Hosmer - Lemeshow Ki-Kare & 7,58 & 3,61 & 5,31 & 4,69 & 4,94 \\
\hline Serbestlik Derecesi & 3 & 4 & 5 & 3 & 4 \\
\hline Hosmer - Lemeshow Anlamlılık & 0,4753 & 0,8901 & 0,7239 & 0,7906 & 0,7641 \\
\hline Doğruluk Yüzdesi (\%) & 66,67 & 73,33 & 78,33 & 75,51 & 79,59 \\
\hline \multicolumn{6}{|l|}{ Katsayı (B) } \\
\hline Sabit (c) & $-4,24 * * *$ & $-7,23$ **** & $-9,36 * * *$ & ,246 &,- 101 \\
\hline WEB & 1,89 **** & $2,09 * * *$ & $2,05^{* * * *}$ & ,378 &,- 523 \\
\hline ODUL &, $109^{*}$ &, $161 * *$ &, $128^{*}$ &, $431 * *$ &, $559 * *$ \\
\hline SURE &, $05^{* * *}$ &, $062 * *$ &, $067 * *$ &,$- 078^{* * * *}$ &,$- 096 * * *$ \\
\hline MINYT_L & & $1,11^{* * *}$ & $1,20 * *$ & & \\
\hline VID & & & $2,51 * *$ & & \\
\hline SAHIPBILGI & & & & & $2,92 * * *$ \\
\hline
\end{tabular}

Not: $* * * p<0,01 ; * * p<0,05 ; * p<0,10$.

Film sektörü için kurulan modellerde ele alınan değişkenlerin tamamının proje başarısı ile pozitif yönlü ve anlamlı bir ilişkiye tespit olduğu tespit edilmiştir. Model 10'a göre web sitesine sahip olma (WEB), ödül sayısı (ODUL) ve fonlama süresi (SURE) değişkenlerinin proje başarısı ile anlamlı ilişkisi bulunmaktadır. Model 11'de bu değişkenlere minimum yatırım tutarı (MINYT) ve Model 12'de ise proje sayfasında proje ile ilgili bilgilendirme yapan video olup olmama durumu (VID) değişkeni eklenmiştir. Buna 
göre, film sektöründeki kitlesel fonlama projelerinde proje sayfasında tanıtıcı bir video bulunması proje başarısı olasılı̆̆ını 2,5 kat artırmaktadır.

Teknoloji sektöründe ise ödül sayısı (ODUL) ve fonlama süresi (SURE) değişkenlerinin proje başarısı ile anlamlı bir ilişkisi bulunduğu gözlenmektedir. Her iki sektörün bütün modellerinde proje başarısına anlamlı bir şekilde etki ettiği belirlenen değişkenler ödül sayısı (ODUL) ve fonlama süresi (SURE) değişkenleridir. Bu sektörde, fonlama süresinin proje başarısı ile ilişkisi ters yönlüdür. Teknoloji sektörü için kurulan her iki modelde de proje sahibinin harici bir web sayfası olması (WEB) proje başarısı ile anlamlı bir ilişkiye sahip değildir. Bu noktada film sektöründen ayrılmaktadır. Model 14'e göre proje sayfasında proje sahibi ile ilgili bilgi bulunması değişkeni (SAHIPBILGI) proje başarısını yüksek düzey anlamlılıkta etkilemektedir.

\section{4. Ülke-Sektör Bulguları}

Analizin son bölümünde örneklemler ülke-sektör kombinasyonlarına ayrılarak modelleme yapılmıştır. Bu bölümdeki örneklemler 30'ar adet projeden oluşmaktadır (bkz. Tablo 1). Türkiye-Film sektörü örnekleminde iki, Türkiye-Teknoloji sektörü örnekleminde bir ve ABD film ve teknoloji sektörlerinde birer olmak üzere toplam beş modelle proje başarısına etki eden faktörler değerlendirilmektedir. Bu analizin bulguları Tablo 8'de sunulmuştur.

Tablo 8'de yer alan -2 Log Likelihood değerlerine göre beş modelin de anlamlı sonuçlar ürettiği görülmektedir (Model 15: -13,9327; $P=0,0033$, Model 16: -10,7460; $P=0,0012$, Model 17: -10,5268; $P=0,0001$, Model 18: -13,4629; $P=0,0021$; Model 19: 11,5764; $P=0,0010)$. Hosmer ve Lemeshow test değerlerinin anlamlı çıkmaması (Model 15: $P=0,2091 ; p>0,05$; Model 16: $P=0,9528 ; p>0,05$; Model 17: $P=0,9492 ; p>0,05$; Model 18: $P=0,5681 ; p>0,05$; Model 19: $P=0,1361 ; p>0,05)$, model-veri uyumunun yeterli düzeyde olduğu anlamına gelmektedir (Çokluk, 2010). Modellerin tahmin yüzdeleri \%73,33 ile \%90 arasında değişmektedir.

Türkiye-Film örneklemini ele alan Model 15'te film sektörü örneklemi ile uyumlu olarak (bkz. Model 10-12) web sitesine sahip olma (WEB), ödül sayısı (ODUL) ve fonlama süresi (SURE) değişkenlerinin proje başarısı ile anlamlı ilişkisi bulunduğu tespit edilmiştir. Model 16'da minimum ve maksimum yatırım tutarlarının proje başarısı ile sırasıyla pozitif ve ters yönlü ilişkisi tespit edilirken bu modele göre fonlama süresi ile proje başarısı arasında anlamlı bir ilişki bulunmamaktadır. Türkiye-Teknoloji örneklemini ele alan Model 17'ye göre minimum ve maksimum yatırım tutarları ile proje sayfasında proje sahibi ile ilgili bilgi bulunması (SAHIPBILGI) değişkenleri ile proje başarısı arasında anlamlı bir ilişki bulunmaktadır. SAHIPBILGI değişkeni ile ilgili bulgu Teknoloji sektörü örneklemini ele alan Model 14'ün bulgusu ile uyumludur. ABD-Film ele alan Model 18'de yalnızca SAHIPBILGI değişkeninin anlamlı ilişsisine işaret etmektedir. ABD-Teknoloji örnekleminin ele alındığı Model 19' da ise minimum ve maksimum yatırım tutarları ile ödül sayısı değişkenlerinin proje başarısı ile anlamlı ilişkisi tespit edilmiştir. Maksimum yatırım 
tutarı katsayısı bu değişkenin ele alındığı diğer modellerde olduğu gibi negatiftir ve ters yönlü ilişkiyi işaret etmektedir.

Tablo: 8

Ülke-Sektör Örneklemlerinden Elde Edilen Lojistik Regresyon Model Sonuçları

\begin{tabular}{|c|c|c|c|c|c|}
\hline & Model 15 & Model 16 & Model 17 & Model 18 & Model 19 \\
\hline Örneklem & TR-Film & TR-Film & TR-Teknoloji & ABD-Film & ABD-Teknoloji \\
\hline -2 Log Likelihood & $-13,9327$ & $-10,7460$ & $-10,5268$ & $-13,4629$ & $-11,5764$ \\
\hline Pseudo R2 & 0,3300 & 0,4832 & 0,49 & 0,3526 & 0,4433 \\
\hline Olasılık > Ki-Kare (P değeri) & 0,0033 & 0,0012 & 0,0001 & 0,0021 & 0,0010 \\
\hline Hosmer - Lemeshow Ki-Kare & 10,87 & 2,68 & 2,75 & 6,71 & 12,35 \\
\hline Serbestlik Derecesi & 3 & 5 & 3 & 3 & 4 \\
\hline Hosmer - Lemeshow Anlamlılık & 0,2091 & 0,9528 & 0,9492 & 0,5681 & 0,1361 \\
\hline Doğruluk Yüzdesi (\%) & 83,33 & 83,33 & 90 & 73,33 & 86,67 \\
\hline \multicolumn{6}{|l|}{ Katsayı (B) } \\
\hline Sabit (c) & $-6,68 * * *$ & $-3,3$ & $-4,62^{*}$ & $-4,07$ & $-2,58$ \\
\hline WEB & $2,01^{*}$ & $2,92 *$ & & & \\
\hline SURE &, $084 *$ & 087 & &,- 002 & \\
\hline VID & $2,78^{* * *}$ & $5,13^{* *}$ & & & \\
\hline MINYT_L & & $2,86^{*}$ & $2,52^{*}$ & & $847^{* *}$ \\
\hline MAKSYT_L & & $-1,63 *$ & $-1,06 * *$ & &,$- 804 *$ \\
\hline SAHIPBILGI & & & $3,16^{* *}$ & & 1,77 \\
\hline ODUL & & & &, $222 * *$ & $853^{* *}$ \\
\hline SOSMED & & & & 1,89 & \\
\hline
\end{tabular}

Not: TR: Türkiye, ABD: Amerika Birleşik Devletleri, *** $p<0,01$; ** $p<0,05$; * $p<0,10$.

\subsection{Bulguların Özeti}

Toplamda 19 modelde 15 değişken ile yapılan analizlerde kitlesel fonlama başarısına etki eden faktörler değerlendirilmiştir. Tablo 9 bütün modellerde anlamlı ilişki tespit edilen değişkenleri anlamlılık dereceleri ile özetlemektedir. Herhangi bir modelde proje başarısı ile anlamlı ilişkisi tespit edilemeyen proje sayfasında yer alan video süresi (VIDSURE), proje sahibi cinsiyeti (CINS), hedeflenen fon miktarı (HEDEF), proje sahibi eğitim durumu (EGTM), proje sahibi sosyal medya bağlantı sayıları (SOSMEDNET) ve proje sahibi yaşı (YAS) değişkenleri bu tabloda yer almamaktadır.

Kurulan modellerde proje başarısı ile en fazla sayıda anlamlı ilişkisi tespit edilen değişken proje sahibinin harici web sitesine sahip olması (WEB) değişkenidir. Bu değişkeni ödül sayısı (ODUL) ve fonlama süresi (SURE) değişkenleri izlemektedir. Fonlama süresi örneklemin bütününde anlamlı bir ilişki göstermese de örneklemin alt kırılımlarında sıklıkla karşımıza çıkmaktadır. Minimum yatırım tutarı değişkeni de (MINYT) değişik örneklem tiplerinde proje başarısı ile anlamlı bir ilişki ortaya koymaktadır. Film sektörü örneklemlerinde proje sayfasında video bulunması değişkeni (VID) proje başarısına pozitif yönlü ve anlamlı etki eden bir değişken olarak karşımıza çıkmaktadır. Maksimum yatırım tutarı değişkeni (MAKSYT) bağımlı değişkenle anlamlı ilişkiye sahip bulunduğu tüm modellerde ters yönlü bir ilişkiye sahiptir. Bir başka ters yönlü ilişki yalnızca Amerika örneklemi ve Teknoloji sektörü örnekleminde fonlama süresi (SURE) proje başarısı arasındadır. Proje sahibinin sosyal medya hesaplarına sahip olması örneklemin tamamı ve Türkiye örneklemi için kurulan modellerde karşımıza çıkmaktadır. 
Tablo: 9

Analiz Bulgularının Özeti

\begin{tabular}{|c|c|c|c|c|c|c|c|c|c|c|}
\hline Model & Örneklem & VID & MINYT & MAKSYT & ODUL & SURE & ACIKKAR & SAHIPBILGI & WEB & SOSMED \\
\hline 1 & Tüm Veri & & & & $* *$ & & & & $* *$ & $*$ \\
\hline 2 & Tüm Veri & & & & & & *** & & *** & $*$ \\
\hline 3 & Tüm Veri & & $* *$ & $*$ & $* *$ & & * & & *** & * \\
\hline 4 & Tüm Veri & & $* *$ & $* *$ & $* *$ & & & $* *$ & *** & \\
\hline 5 & TR & & & & & * & & & & $*$ \\
\hline 6 & TR & & & & & & & $* *$ & & \\
\hline 7 & TR & & & & & *** & & & & * \\
\hline 8 & ABD & & & & & *** & & & $* * *$ & \\
\hline 9 & ABD & & $* *$ & $* *$ & $* *$ & ** & & & $* * *$ & \\
\hline 10 & Film & & & & $*$ & *** & & & $* * *$ & \\
\hline 11 & Film & & $* *$ & & $* *$ & *** & & & ***** & \\
\hline 12 & Film & $* *$ & $* *$ & & $*$ & *** & & & $* * *$ & \\
\hline 13 & Teknoloji & & & & *** & **** & & & & \\
\hline 14 & Teknoloji & & & & *** & $* * *$ & & **** & & \\
\hline 15 & \begin{tabular}{|l|} 
TR-Film \\
\end{tabular} & *** & & & & * & & & $*$ & \\
\hline 16 & \begin{tabular}{|l|} 
TR-Film \\
\end{tabular} & *** & * & $*$ & & & & & $*$ & \\
\hline 17 & TR-Tekno. & & * & *** & & & & ** & & \\
\hline 18 & ABD-Film & & & & *** & & & & & \\
\hline 19 & ABD-Tekno. & & $* *$ & $*$ & *** & & & & & \\
\hline
\end{tabular}

Not: TR: Türkiye, ABD: Amerika Birleşik Devletleri, *** $p<0,01,{ }^{*} p<0,05,{ }^{*} p<0,10$.

\section{Tartışma}

$\mathrm{Bu}$ bölümde, gerçekleştirilen ampirik analiz sonuçları literatürdeki bulgular, ele alınan temel teoriler (Sinyal Teorisi ve Sosyal Ă̆ Teorisi) ve bunlar 1şığında belirlenen hipotezler kapsamında özetlenerek tartışılmaktadır.

Öncelikli bulgu olarak, proje sahibinin cinsiyeti, eğitim durumu, yaşı, proje hedeflenen fon miktarı, video süresi ve sosyal medya bağlantı sayısı değişkenlerinin kurulan modellerin anlamlılığına olumlu bir katkıda bulunmadığı, dolayısıyla proje başarısına etki etmediği gözlenmiştir. Benzer bir biçimde, Levin (2015) ile Marom vd. (2018) projenin desteklenme durumunun proje sahibi cinsiyetine bağlı olmadığını savunmaktadır. Marom vd. (2018)'e göre proje sahibi eğitim durumundaki farklılıkların kitlesel fonlama projesine anlamlı bir sonuçta etkisi bulunmamıştır. Benzer şekilde, Levin'in (2015) yaptığ araştırmaya göre bir kitlesel fonlama projesine destekçiler tarafindan destek verilmesi kararı proje sahibinin yaşı gibi özelliklerden de etkilenmemektedir. Kohli vd. (2016)'nin araştırması da fon desteği miktarları ile video uzunluğunun proje başarısı ile önemli ölçüde ilişkili olmadığını göstermiştir. Dolayısıyla, cinsiyet, eğitim durumu, yaş, hedeflenen fon miktarı ve video süresi değişkenleri açısından bu çalışmanın bulguları literatürdeki bulgularla uyumludur. Ancak, sosyal ağ sitelerinde daha çok bağlantı sayısına sahip olan proje sahibinin proje başarısının daha yüksek olacağını savunan Mollick (2014)'ün aksine sosyal medya bağlantı sayısı ile proje başarısı arasında olumlu yönde bir ilişki olduğu hipotezi doğrulanamamaktadır.

$\mathrm{Bu}$ çalışmadaki analiz sonuçlarına göre fonlama konusu veya yer aldığı ülke fark etmeksizin kurulan modellerin çoğunluğunda yatırımcının dikkatini çekeceğini savunan ve sinyal teorisini destekleyecek şekilde proje başarısı ile proje sahibinin harici bir web sitesine sahip olması arasında olumlu yönde ilişki olduğu tespit edilmiştir. Analiz sonuçları, proje 
sahibinin web sayfasına sahip olmasının kitlesel fonlama proje sonucuyla pozitif bir ilişki verdiğini savunan Drablos (2015)'un ve Skirnevsky vd. (2017)'nin çalışmaları ile uyum sağlamaktadır. Genel itibari ile, proje sayfasında proje sahibinin harici bir web sayfasına sahip olma durumu ile proje başarısı arasında olumlu bir ilişki vardır hipotezi doğrulanmaktadır.

Ödül sayısının, tüm verilere ilişkin model sonuçlarında proje başarısı ile olumlu yönde bir etkisi olduğu gözlemlenmiştir. Analiz sonucunda elde edilen sonuçlar ödül sayısı ile proje başarısı arasında olumlu bir ilişki vardır hipotezini doğrulamaktadır. Kunz vd. (2016)'ne göre çok sayıda ödül olması potansiyel destekçilerin özelliklerine ve ihtiyaçlarına göre zaman harcandığını ve çaba gösterildiğinin algılanmasını sağlamaktadır. Öte yandan, karışıklık olmaması adına ödül sayısının az olması gerektiğini savunan Forbes ve Schafer (2017) ile basit bir ödül sisteminin olmasının destekçilerin ilgisini çekeceğini savunan Leite ve Moutinho (2012)'nun çalışmaları ile çalışma sonuçları uyum sağlamamaktadır.

Projenin fonlama süresinin Türkiye ve film sektörü örneklemlerinde gerçekleştirilen analiz sonuçlarına göre proje başarısını pozitif yönde etkilediği tahmin edilmektedir. Proje başarısı ile fonlama süresi arasında pozitif bir ilişki olduğunu rapor eden Cordova vd. (2015) ve Burtch vd. (2013) ile bu çalışmada yer alan analiz sonuçları uyum sağlamaktadır. Bu çalışmada elde edilen Türkiye ve film sektörü verilerine ilişkin sonuçlar, fonlama süresi ile proje başarısı arasında olumlu bir ilişki vardır hipotezini doğrulamaktadır. Bunun aksine, Amerika ve teknoloji verilerine göre fonlama süresi proje başarısını negatif yönde etkilemektedir. Kunz vd. (2016), Mollick (2014) ve Claus vd. (2017) çalışmalarında başarı ile proje arasında negatif ilişki olduğunu rapor ederken açıklama olarak fonlama süresinin uzamasının olumsuz yönde bir güven eksikliğine sebep olduğunu belirtmektedirler.

Analiz sonuçlarına göre, proje sayfasında yer alan ödüllerin minimum yatırım tutarı projenin başarısını pozitif yönde etkilemektedir. Ancak bu durum Kıran (2013)'ın, yatırım miktarı ne kadar küçük olursa yatırımcı daha çok katkıda bulunacaktır görüşü ile minimum yatırım tutarının düşük tutulmasını savunun Forbes ve Schaefer (2017)'in çalışmaları ile uyum sağlamamaktadır. Sonuç olarak analiz sonuçları, minimum yatırım tutarı ile proje başarısı arasında olumlu yönde bir ilişki yoktur hipotezini doğrulamamaktadır.

Kitlesel fonlama projelerinin proje sayfasında yer alan ödüllerin maksimum yatırım tutarı ile proje başarısı arasında negatif yönlü bir ilişkisi olduğu gözlemlenmiştir. Maksimum yatırım tutarı literatürde analizlere yeteri kadar konu edilmemiştir. Analiz sonuçları maksimum yatırım tutarı ile proje başarısı arasında olumlu yönde bir ilişki vardır hipotezini doğrulamamaktadır. Analiz sonuçlarına göre maksimum yatırım tutarı azaldıkça proje başarısı artacaktır tahmini yapılabilmektedir.

Proje sayfasında proje sahibi hakkında bilgi olup olmaması sinyal teorisini destekleyecek şekilde proje başarısı ile pozitif ilişkili olduğu sonucuna ulaşılmıştır. Proje sahibinin veya ekibin kitlesel fonlama platformundaki proje sayfasında kişisel bilgilerinin bulunması potansiyel yatırımcılara güven ve ciddiyet vererek olumlu bir etki yaratacağına 
araştırmalarında yer veren Boeuf vd. (2014) ile proje sayfasında proje sahipleri hakkında bilgilerin yer almasının olumlu bir etki yaratacağını savunan Colombo vd. (2014) ve projenin yasallığını artıracağını savunan Frydrych (2014)'in çalışmaları ile analiz sonuçları uyum sağlamaktadır. Analiz sonuçları ve literatür araştırmaları, proje sahipleri hakkında bilgi ile proje başarısı arasında olumlu ilişki vardır hipotezini doğrulamaktadır.

Proje sahiplerinin sosyal medya hesaplarına sahip olması sosyal ağ teorisinin tanınırlığı artırması yönünden desteklediği şekilde proje başarısına olumlu yönde bir etkisi olduğu sonucu elde edilmiştir Proje sahibinin sosyal medya hesaplarına sahip olması Lu vd. (2014)'nin çalışmasıyla uyum sağlamaktadır. Proje sahibinin sosyal medya sayfalarını gören destekçiler projeyi kendileriyle özdeşleştirerek daha çok kişiye ulaştırmakta ve projenin başarısına katkı sağlamaktadır (Kromidha \& Robson, 2016). Çalışmada elde edilen sonuçlar, proje sahibinin sosyal medya hesabına sahip olma durumu ile proje başarısı arasında olumlu bir ilişki vardır hipotezini doğrulamaktadır.

Proje sayfasında video olup olmaması çalışmada yer alan analiz sonuçları, girişimciler ile destekçiler arasındaki bilgi asimetrisini azaltmakla ilgilenen Petitjean (2018) ile ödül temelli bir projenin başlangıcında bir videonun varlığının olmasının kitlesel fonlama projesinin başarıya ulaşma ihtimalini artırdığını savunan Marom, Sade ve Gafni (2018)'nin çalışmaları ile uyumlu bir sonuçtur. Kunz vd. (2016)'ne göre videoların sayısının proje başarısının artmasına neden olabilecek pozitif bir sinyal görevi görebilmektedir. Analiz sonuçlarına göre video olup olmaması Film ve Türkiye-Film kategorilerinde anlamlı ve proje başarısıyla pozitif yönde ilişkili olarak sonuç vermektedir. Projenin videoya sahip olması ile proje başarısı arasında olumlu yönde bir ilişki vardır hipotezi doğrulanmaktadır.

Projelerin tanıtımının yapıldığı açıklama uzunluklarının tüm verilere ilişkin sonuçlara göre proje başarısını olumlu yönde etkilediği tahmin edilmektedir. Lounsbury ve Glynn (2001)'nin çalışmaları analiz sonuçları ile uyum sağlamaktadır. Mollick'e (2014) göre proje sayfasındaki ayrıntılı açıklamalar yatırımcıların şüphelerinden biri olan dolandırıcılık algısını azaltacaktır. Analiz sonuçları, proje açıklama uzunluğu karakter sayısı ile proje başarısı arasında olumlu yönde bir ilişki vardır hipotezini doğrulamaktadır.

Çalışmada yer alan analiz sonuçlarını ülkeler bazında incelemek de mümkündür. Sadece Türkiye verileri incelendiğinde fonlama süresi, sosyal medya hesaplarına sahip olma durumu ile proje sahibi hakkında bilgi olması proje başarısı ile pozitif yönde ilişkilidir sonucuna ulaşılmıştır. Dolayısıyla Türkiye'de yürütülen kitlesel fonlama projelerinde fonlama süresi arttıkça, proje sahibi sosyal medyada ulaşılabilir oldukça ve proje sahibi hakkında bilgiye proje sayfasında yer verildikçe proje başarısı artacağı tahmin edilebilir.

ABD verilerinden elde sonuçlara göre kitlesel fonlama projelerinin fonlama süreleri Türkiye'nin aksine proje başarısı ile negatif yönde bir ilişkiye işaret etmektedir. Fonlama süresinin kısalması ABD'de yürütülen kitlesel fonlama projeleri için proje başarısını artıracağı tahminlenebilir. Bunun yanı sıra, proje sahibinin harici web sayfasına sahip olma durumunun ABD'de yürütülen kitlesel fonlama projeleri için proje başarısını yüksek 
olasılıkla pozitif olarak etkilediği tahmin edilebilir. Minimum ve maksimum yatırım tutarı eklenerek oluşturulan bir diğer model ile Amerika için ödül sayısı ve minimum yatırım tutarının proje başarısı ile pozitif bir ilişkisi olduğu, maksimum yatırım tutarı ile negatif yönde bir ilişkisi olduğu tespit edilmiştir.

Son olarak, analiz bulguları ele alınan iki ayrı sektör açısından da değerlendirilebilir. Analiz bulgularına göre fonlama konusu film verilerine ilişkin kurulan modellerde (Amerika-Film kategorisi hariç) proje başarısı ile yatırımcının dikkatini çekeceğini savunulan proje sahibinin harici bir web sitesine sahip olması arasinda sinyal teorisini destekleyen bir biçimde pozitif yönde ilişki olduğu tespit edilmiştir. Bu sektörde, ayrıca ödül sayısı, fonlama süresi, minimum yatırım tutarı ve projenin videoya sahip olup olmamasının da proje başarısını olumlu yönde etkilediği gözlenmektedir. Teknoloji sektörü bulgularına göre ise proje ödül sayısı arttıkça ve proje sayfasında proje sahibi hakkında bilgiye yer verildikçe proje başarısı artmaktadır. Bu sektörde, fonlama süresinin film projelerinin aksine proje başarısı ile negatif yönlü bir ilişkisi olduğu gözlenmiştir.

\section{Sonuç}

$\mathrm{Bu}$ çalışma, kitlesel fonlama başarısını etkileyen faktörlere kitlesel fonlama platformlarından toplanan proje bilgileri vasitasıyla detaylı bir inceleme sunmayı amaçlamaktadır. Bu amaç doğrultusunda Türkiye ve Amerika Birleşik Devletleri’ndeki kitlesel fonlama platformlarından elde edilen başarılı ve başarısız kitlesel fonlama projelerine ait veriler 15 değişken açısından 19 ayrı modelle analiz edilmiş ve bulguları sunulmuştur. Bulgular, örneklemin seçildiği ülke veya sektöre göre farklılıklar gösterse de genel anlamı ile kitlesel fonlama projelerinin başarısını inceleyen uluslararası literatür ile oldukça uyumludur. Sonuçlar ülkeler ve sektörler bazında karşılaştırılmış Türkiye ve ABD örneklemleri ile Teknoloji ve Film sektörleri örneklemleri açısından farklılıklar ortaya konmuştur. Türkiye'de her geçen gün yaygınlaşan kitlesel fonlama projeleri için çalışmanın bulgularının proje sahipliği yürütmek isteyen girişimciler veya bu projelerin etkinliğini araştıracak çalışmalar için yol gösterici nitelikte olacağı düşünülmektedir. İlerleyen çalışmalarda örneklemlerin ülkeler ve sektörler bazında geliştirilmesi düşünülebilir.

\section{Kaynaklar}

Agrawal, A. et al. (2011), “The Geography of Crowdfunding”, NBER Working Paper 16820.

Alois, J.D. (2014), Crowdfund Global Expo Shares Encouraging Data on Crowdfunding, Crowdfund Insider.

Atsan, N. \& E.O. Erdoğan (2015), "Girişimciler İçin Alternatif Bir Finansman Yöntemi: Kitlesel Fonlama (Crowdfunding)”, Eskişehir Osmangazi IIIBF Dergisi, 10(1), 297-320.

Audretsch, D.B. et al. (2012), "Financial signaling by innovative nascent ventures: the relevance of patents and prototypes", Research Policy, 41(8), 1407-1421.

Bakshy, E. et al. (2012), "The role of social networks in information diffusion", Proceedings of the 21 st International Conference on World Wide Web, 519-528. 
Belleflamme, P. et al. (2012), "Crowdfunding: Tapping the Right Crowd”, Journal of Business Venturing, 29(5), 585-609.

Boeuf, B. et al. (2014), "Financing Creativity:Crowdfunding as a New Approach for Theatre Projects", International Journal of Arts Management, 16(3), 33-48.

Borgatti, S.P. et al. (2014) "Social network research: confusions, criticisms, and controversies", Research in the Sociology of Organizations, 40, 1-29.

Borst, I. et al. (2017), "From Friendfunding to Crowdfunding: Relevance of Relationships, Social Media, and Platform Activities to Crowdfunding Performance", New Media \& Society, 119.

Burtch, G. et al. (2013), "An Empirical Examination of The Antecedents And Consequences of Investment Patterns In Crowd-funded Markets", SSRN Electronic Journal. Information Systems Research, 24(3), 499-519.

Chen, S. et al. (2016), "What Really Makes a Promotional Campaign Succeed on Crowdfunding Platform", Journal of Advertising Research, 6(1), 81-94.

Clauss, T. et al. (2017), "Directing the wisdom of the crowd : the importance of social interaction among founders and the crowd during crowdfunding campaigns", Economics of Innovation and New Technology, 27(8), 709-729.

Colombo, M. et al. (2014), "Internal Social Capital and the Attraction of Early Contributions in Crowdfunding", Entrepreneurship Theory and Practice, 39(1), 75-100.

Cordova, A. et al. (2015), "The Determinants of Crowdfunding Success: Evidence from Technology Projects", Procedia - Social and Behavioral Sciences, 181, 115-124.

Çokluk, O. vd. (2010), Sosyal bilimler için çok değişkenli istatistik SPSS ve LISREL Uygulamaları, Ankara: Pegem.

Çonkar, M.K. \& M.F. Canbaz (2018), "Kitle Fonlaması Finansman Yöntemi: Türkiye'de Sistemin Geliştirilmesine Yönelik Öneriler”, Optimum Ekonomi ve Yönetim Bilimleri Dergisi, 5(2), 119-132.

Drablos, C. (2015), "What Influences Crowdfunding Campaign Success", Unpublished Master Thesis, University of Agder, Faculty of Economics and Social Science, Department of Economics and Business Administration, Norway.

Forbes, H. \& D. Schaefer (2017), "Guidelines for Successful Crowdfunding”, Procedia CIRP, 60, 398-403.

Frydrych, D. et al. (2014), "Exploring Entrepreneurial Legitimacy in Reward-based Crowdfunding", Venture Capital, 16(3), 247-269.

Gerber, E.M. et al. (2012), "Crowdfunding: Why people are motivated to post and fund projects on crowdfunding platforms", in Proceedings of the International Workshop on Design, Influence, and Social Technologies: Techniques, Impacts and Ethics, 2(11), 10.

Griffin, Z. (2012), "Crowdfunding: Fleecing the American Masses”, Case Western Reserve Journal of Law, Technology \& the Internet, 4, 375.

Gulati, S. (2014), “Crowdfunding: A Kick Stater for Startups”, Special Report, TD Economics.

Howe, J. (2006), "The Rise of Crowdsourcing", Wired Magazin, <http://archive.wired.com/wired/archive/14.06/crowds.html>, 21.02.2015. 
Hui, J. et al. (2014), "Understanding and leveraging social networks for crowdfunding: implications for support tools", in CHI'14 Extended Abstracts on Human Factors in Computing Systems, 2083-2088.

InfoDev/The World Bank (2013), Crowdfunding's Potential for the Developing World; Finance and Private Sector Development Department, Washington, DC: World Bank.

Kıran, T. (2013), “Sermaye Piyasalarında Kitle Fonlaması”, Yeterlilik Etüdü, Sermaye Piyasası Kurulu Ortaklıklar Finansmanı Dairesi.

Kromidha, E. \& P. Robson (2016), "Social Identity and Signalling Success Factors in Online Crowdfunding”, Entrepreneurship \& Regional Development, 28(9-10), 605-629.

Kunz, M.M. et al. (2016), “An Empirical Investigation of Signaling in Reward-based Crowdfunding", Electronic Commerce Research, 17(3), 425-461.

Kuppuswamy, V. \& B.L. Bayus (2013), "Crowdfunding Creative Ideas: The Dynamics of Projects Backers", in The economics of crowdfunding, 151-182, Palgrave Macmillan, Cham.

Lacan, C. \& P. Desmet (2017), "Motivations for Participation and e-WOM Among Supporters of Crowdfunding Campaigns", in Strategic innovative marketing, 315-321, Springer, Cham.

Lehner, O.M. (2013), "Crowdfunding social ventures: a model and research agenda”, Venture Capital, 15(4), 289-311.

Leite, P.M. \& N. Moutinho (2012), "Innovation Through Crowdfunding: A Quantitative and Qualitative Analysis of Kickstarter", in CINET 2012: 13th International CINet Conference, Continuous Innovation Across Boundaries.

Levin, F. (2015), "Success Determinants of Crowdfunding Projects", Review of Business and Economics Studies, 3(4), 79-87.

Lounsbury, M. \& M.A. Glynn (2001), “Cultural Entrepreneurship: Stories, Legitimacy, and the Acquisition of Resources", Strategic Management Journal, 22(6-7), 545-564.

Lu, C.T. et al. (2014), "Inferring the Impacts of Social Media on Crowdfunding", WSDM'14, February 24-28, New York, USA.

Marom, D. et al. (2018), "Are the Life and Death of an Early Stage Venture Indeed in the Power of the Tongue? Lessons from Online Crowdfunding Pitches", Leeds \& Kauffman Crowdfunding Conference, Jerusalem.

Mollick, E. (2014), “The Dynamics of Crowdfunding: An Exploratory Study”, Journal of Business Venturing, 29(1), 1-16.

Ordanini, A. et al. (2011), "Crowdfunding: Transforming customers into investors through innovative service platforms", Journal of Service Management, 22(4), 443-470.

Petitjean, M. (2018), "What explains the success of reward-based crowdfunding campaigns as they unfold? Evidence from the French crowdfunding platform KissKissBankBank", Finance Research Letters, 26, 9-14.

Sancak, E. (2016), "Applicability and Readiness of Crowdfunding in Turkey", International Journal of Business and Social Science, 7(1), 99-110.

Skirnevsky, V. et al. (2017), "The Influence of Internal Social Capital on Serial Creators' Success in Crowdfunding", Entrepreneurship Theory and Practice, 41(2), 209-236.

Spence, M. (1973), “Job Market Signaling”, The Quarterly Journal of Economics, 87(3), 355-374. 
Spence, M. (2002), "Signaling in retrospect and the informational structure of markets", American Economic Review, 92, 434-459.

Swaminathan, S. \& R. Kent (2013), "Second-by-Second Analysis of Advertising Exposure in TV Pods: The Dynamics of Position, Length, and Timing", Journal of Advertising Research, 53(1), 91-100.

Şahinoğlu, E. (2019), “Kitlesel Fonlama Başarı Faktörleri: Türkiye'de Ödül Bazlı Kitlesel Fonlama Projelerinin Durumu", Yüksek Lisans Tezi, Kırklareli.

Ünsal, S. (2017), Kitlesel Fonlama, İş Yapma Yöntemini Değiştirecek Yeni Sistem, İstanbul: Ceres Yayınlar1.

Valanciene, L. \& S. Jegeleviciute (2013), "Valuation of Crowdfunding: Benefits and Drawbacks", Economics and Management, 18(1), 39-48.

Valanciene, L. \& S. Jegeleviciute (2014), "Crowdfunding for creating value: stakeholder approach", Procedia-Social and Behavioral Sciences, 156, 599-604.

Wang, N. et al. (2015), "How to Crowdfund More: A Signaling Perspective", DIGIT 2015 Proceedings, 15. 
Akyıldız, B. \& S. Metin-Camgöz \& K.B. Atıcı (2021), "Kitlesel Fonlama Projelerinin Başarılarını Etkileyen Faktörler Üzerine Bir İnceleme”, Sosyoekonomi, 29(50), 521-545. 